\section{Yhtenäisestä poikakulttuurista moninaisiin maskuliinisuuksiin}

Kivijärvi, Antti, Huuki, Tuija \& Lunabba, Harry (2018). Poikatutkimus. Vastapaino. 337 sivua.

POIKATUTKIMUS ON KAUAN odotettu katsaus ja vertaisarvioitu kokoomateos suomalaiseen poika- ja maskuliinisuustutkimukseen. Toimittajat ovat laajasti lasten ja nuorten elämään perehtyneitä sosiaalityön, nuorisotyön ja sukupuolentutkimuksen tutkijoita.

POIKIA JA POIKANA ELÄMISTA SITOVAT KÄYTÄNNÖT

Lastemme ja nuortemme elämismaailma on yhä sukupuolittunut, vaikka julkinen keskustelu tuntuu välillä edistykselliseltä ja teemasta on tutkimusta. Kulttuuriset ja institutionaaliset rakenteet ja näiden sisällä konstruoidut diskurssit monistavat edelleen paikoin hyvinkin stereotyyppistä kuvaa pojista ja tytöistä. Tätä tuo esille teoksen läpi kulkevan hegemonisen maskuliinisuuden valta-asema, jota kuvataan muun muass määritteillä 'hallitsevuus', 'toiminnallisuus', 'suoriutuvuus', 'fyysinen voima', 'tunteiden kontrolli' ja 'urheilullisuus'.

'Hegemonisella maskuliinisuudella' viitataan tietynlaisen maskuliinisuuden normatiiviseen asemaan yhteiskunnassa ja sen tuottamiin käsityksiin siitä, mitä poikien oletetaan olevan ja minkälaisia heidän tulisi olla. Suomalaisessa kulttuurissa ja keskustelussa äijämäisyyttä ja kovia miesarvoja ihannoidaan, mutta rinnalle on nousemassa sellaisia käsitteit kuin 'tunteiden näyttäminen' 'tunteellisuus', 'haavoittuvuus' $\mathrm{ja}$ 'herkkyys'.

Teos tuo tarkoituksenmukaisesti esiin kulttuurin kaksijakoisuutta ja nostaa sen rinnalle luokka-asemaa, alueellisuutta, etnisyyttä ja monia muita tekijöitä jotka ovat vaikuttamassa sukupuolittuneita käytäntöjä monipuolistavasti ja kyseenalaistaen. Kirjoittajat haluavat tuoda esiin monenlaisia poikia ja poikien elämismaailman monimuotoisuutt ja purkaa samalla sukupuolittuneita käytäntöjä.

Teoksessa tuodaan optimistisesti esille kasvattajien ja poikien itsensä valtautumisen tavoite. Se on oivallus siitä, että pojat voivat ylittää heille asetetut ahtaat sukupuolinormit. Näin voitaisiin lisät poikien koulumyönteisyyttä ja lukuintoa, parantaa tunnetaitoja ja jopa monipuolistaa harrastusvalikoimaa. Näiden toteutuminen johtaisi kirjoittajien mukaan aikuisuudessa nykyistä vähemmän sukupuolittuneisiin työmarkkinoihin, demokraattisimpiin perhemalleihin ja vähäisempään naisiin kohdistuvaan väkivaltaan Eli asiat eivät ole millään tavoin pieniä ja marginaalisia.

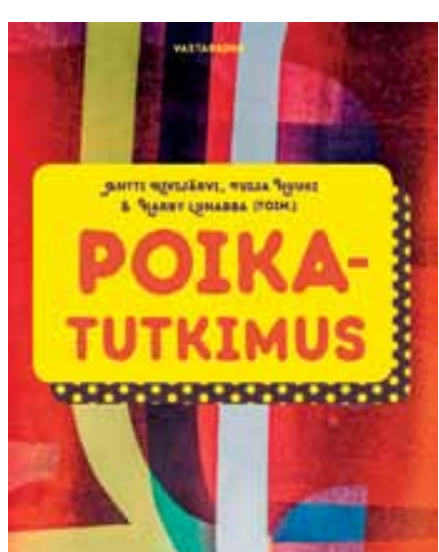

TODELLISUUTTA LUOVAT KÄSITTEET

Teos jakaantuu neljään eri teemaalueeseen. Kirian avaavassa "Pojat ajassa" -luvussa käsitellään muun muassa poikakysymyksen sekä miehen mallin' syntyä. Lisäksi taustoitetaan 'sukupuoliroolin' käsitteen syntyä ja saapumist Suomeen. Kirjoittajat piirtävät tarkoituksenmukaisesti poikana olemisen ajallista ulottuvuutt kytkemällä sen kulloiseenkin yhteiskunnalliseen ja historialliseen kontekstiinsa.

Poikia, poikakysymystä ja poikia koskevaa keskustelua on tärkeää tarkastella historiallisessa jatkumossa, jotta ymmärretään nykyistä poika- ja sukupuolikeskustelua. Lauri Julkunen pohdiskelee artikkelinsa lopussa Julia Grantia lainaten, ovatko 1900-luvun alkupuolen poikakysymys ja sen ratkaisuksi kehitetty poikakasvatus olleet synnyttämässä nykyisiä poikaongelmia.

"Pojat ja koulu" -luvussa keskusteluun nousevat poikien koulu- ja hyvinvointiasiat ja nostona

IHAILLUN ÄIJÄMÄISYYDEN RINNALLE

OVAT NOUSEMASSA ESIMERKIKSI

TUNTEIDEN NÄYTTÄMINEN JA HERKKYYS.

ei-heteroseksuaalisten poikien ja transnuorten kokemukset ja valinnat koulutuksessa”.

Ensimmäisissä luvuissa esitellään käsitteet ja samalla niiden voima. Keskeisinä esiin nousevat muun muassa 'miehen malli'-käsite ja "pojat on poikia"-diskurssi, jotka ovat piirtyneet syvään meihin kaikkiin, etenkin poikiin ja miehiin. Ilana Aalto kuvaa, miten 'miehen malli' tuotettiin perusteluna poikien tarpeeseen: $s$ oli jotain, mitä pojat tarvitsivat. Ei kuitenkaan juurikaan pohdittu, millainen mies olisi sopiva pojalle miehen malliksi.

\section{MASKULIININEN VÄKIVALTA} JA YHTEISÖLLISYYS

Kolmannessa, "Pojat, haavoittuvuus ja haavoittavuus" -luvuss keskusteluun tuodaan pojat ja heihin usein liitetty väkivalta ja koulusurmat Tuija Huuki tarkastelee poikia ja väkivaltaa kolmen metodologisen lähestymistavan alossa. Hän kuvaa analyysiaan videoidusta tutkimusaineistost erään pohjoissuomalaisen päivàkodin pihasta. Artikkelissa yhdistyvät teoksen kantavat teemat ahtaat sukupuoliroolit, poikia varjostavat ennakkokäsitykset, asten sukupuolten väliset valtasuhteet, maskuliininen väkivalta normatiiviset ja institutionaalise käytännöt sekä vallan ja sukupuolten monimutkaiset ilmenemismuodot.

Huuki tekee kuten kehottaa: valtasuhteiden moninaisuutta tulee tehdä kokonaisvaltaisemmall tavalla näkyväksi esimerkiksi uusmaterialististen tutkimusmenetemien avulla

"Pojat yhteisössä" -luvussa kuvataan poikien ystävyyssuhteita ja tilankäyttöä sekä maahanmuuttajataustaisia poikia ja nuoria miehi koskevaa tutkimusta. Päätösluvussa kuvataan poikien hyviä edellytyksiä pitää yllä ystävyyssuhteita ja antaa vertaistukea. Samalla piirretään kuvaa hyvin päriäävistä tavallisista pojista ja heidän arjestaan.

MONIMUOTOISUUS KOUKUTTAA

Teos lupaa monipuolistaa kuvaa pojista ja poikuudesta, tuoda esille poikana olemisen moninaisia mahdollisuuksia ja antaa eväitä lukijalle jäsentää kriittisesti poikia koskevia julkisia keskusteluita. Se pitää lupauksensa - ja antaa lukijalleen vielä enemmän: se ava lukijan kriittisen mielen ikkunan yhteiskunnallisiin sukupuolisensitiivisiin kysymyksiin ja sytyttää kipinän tarkastella arjen sukupuolittuneita käytäntöjä.

Teos koukuttaa lukijan monimuotoisuudellaan: se tuo esiin keskusteluja pojista, moninaisista maskuliinisuuksista ja poikakulttuurin historian tarkastelusta ain tuoreisiin teemoihin maahanmuuttajapojista ja transnuorten ammatinvalinnoista. Lukija jäa vielä odottamaan keskustelua ja kokoavaa tutkimusta sateenkaariperheistä ja kahden miehen perheistä, aikuisista ja ikääntyneistä miehistä ja heidän elämästään

JENNI HUHTASALO

YTM, väitöskirjatutkija,

koulutusasiantuntija

Turun yliopiston

,

Porin yksikkö 